\title{
Empowering people to protect environment: A case study of PT. Indaco Warna Dunia's CSR
}

\author{
Sri Hilmi Pujihartati ${ }^{*}$ Ismi Dwi Astuti Nurhaeni, Drajat Tri Kartono, and Argyo Demartoto \\ Fakultas Ilmu Sosial dan Politik, Universitas Sebelas Maret, Surakarta, Indonesia
}

\begin{abstract}
Corporate social responsibility is a company obligation to be responsible on the social atmosphere besides being able to improve the company's image. In addition to corporate benefits, CSR can contribute to environmental-based participatory community empowerment. This paper explores the environmental empowerment carried out by the CSR of PT. Indaco Warna Dunia that collaborates with the surrounding community. This research uses a case study approach. Data collection was carried out by observation, in-depth interviews, and literature study. The results showed that the empowerment does many empowering and sustainable act to save environment. The programs are reforestation, environmental education through festivities, applying green concept in a building, hydroponic education, garbage bank, and etc. The contribution felt by the community is considered real and beneficial in a sustainable manner. The CSR uses unique strategy to empower people to protect environment in creative manners.
\end{abstract}

\section{Introduction}

The development of residential areas, industrial areas, or reforestation areas often ignores environmental sustainability and only considers economic benefits. In addition, poor environmental management can at least be caused by many factors such as education level, economic problems, lifestyle, weak legal system, and weak environmental management and supervision, which can cause environmental pollution and damage. However, there is still no real legal action for the perpetrators of environmental pollution.

Problems and challenges in environmental management today require a paradigm shift in realizing every step of the way. The old paradigm that only solves short-term problems (such as waste management using the transport-waste principle) must shift to a new paradigm that is sustainable in nature (such as $3 \mathrm{R}$ waste management). Therefore, every step must involve the community. Without community participation, no strategy can last long. The role of the community must be seen as dynamic and provide an opportunity for other stakeholders such as the

* Corresponding author: srihilmi@staff.uns.ac.id 
government to succeed in a sustainable environment as stated in the Sustainable Development Goals (SDGs).

The relationship between natural resources and the environment is always closely related to sustainable development. In any sustainable development, it will definitely affect natural resources and the environment. The impact of sustainable development will lead to economic, social and environmental sectors. However, Indonesia's sustainable development has always been regarded as rapid economic growth. It should be recognized that the benchmark for the success of sustainable development is not just economic factors. There are other factors that need to be considered in sustainable development, namely society and ecology. These three factors are called the three pillars of sustainable development [1].

In Indonesia itself, it is not enough to just rely on three pillars, five pillars of sustainable development should be applied, namely social, economic, ecological, environmental institutions, and law enforcement [2]. With this, it is hoped that the management of natural resources and the environment will not only be managed and sufficient for now but also be sufficient for future generations. Sustainable development is defined as development that meets present needs without compromising future needs [3].

The dimensions of the environment in development according to Saptari [4] are Creating generational internal justice and Maintaining the harmony of human relations with the environment. In the use of natural resources and the environment to improve the quality of life, it must be based on the consideration that over a period of time, natural resources and the environment are used by more than one community group with different interests. The polluter pays principle approach is applied to bridge the different interests of natural resource users, both in the function of receiving raw materials or receiving waste. In carrying out efforts to maintain natural resources and the environment through the polluter pays principle approach, benchmarks are used, for example, environmental quality standards set based on the ability to adapt to the environment against disturbances caused by activities utilizing natural resources and the environment. This approach, apart from being able to resolve conflicts in society, will also create a harmonious relationship between humans and the environment.

There are various studies on community empowerment in environmental conservation that effectively have a positive contribution to the environment in Indonesia. Researches related to this have been discussed in various journal articles. These studies include community empowerment research that focuses on the community environment [5-7], community empowerment through waste banks [8-10] and community empowerment in waste management. These studies show the importance of community empowerment processes in environmental conservation in promoting environmental quality improvement with an emphasis on the importance of community participation.

Community empowerment is one way to promote and encourage environmental conservation in the community. This study seeks to explore the process of community empowerment in environmental conservation in the Harmoni Village through the CSR program of PT. Indaco Warna Dunia. If referring to previous references that explain the empowerment process that is short-term and monolithic (one way), the community empowerment process in Harmoni Village (based on 
preliminary observations) uses a long-term or sustainability approach and is integrated into various ways from various aspects. Community empowerment carried out by the company's CSR does not only focus on conventional ways of promoting environmental conservation. Educational, economic, social, and environmental approaches are integrated into a model of community empowerment through CSR programs to encourage environmental conservation. The integration model is an aspect of the novelty of this research that is interesting to be explored further.

The growth of large industries in Karanganyar is considered to have contributed to the emergence of environmental problems. Based on information from the Central Bureau of Statistics of Karanganyar Regency, medium and large industries in Karanganyar Regency (2016) were 148 units with the highest number found in Jaten District, namely 88 units. Then followed by Kebakkramat District with 20 units, Gondangrejo District with 16 units, and Colomadu District with 13 units. These industries are able to absorb as many as 41,907 workers.

Rapid industrial growth affects the quality of natural resources and even changes the color of the surrounding environment. Besides that, it affects the socioeconomic and cultural surrounding communities as well as the emergence of environmental pollution caused by the waste produced. Negative impacts on environmental pollution such as water pollution, air pollution, soil pollution, and others endanger the survival of all creatures.

On the other hand, companies in Karanganyar also have social responsibility. Companies are no longer faced with responsibilities that are based on the aspect of economic profit only, namely the value of the company reflected in its financial condition, but must also pay attention to social and environmental aspects, or what is commonly called the Three Bottom Line. The synergy of these three elements is key to the concept of sustainable development.

PT. Indaco Warna Dunia as a company located in Karanganyar has a social responsibility to help the community in managing environmental problems. Harmoni Foundation is a CSR institution of PT. Indaco Colors of the World. Historically, PT Indaco Warna Dunia started operating in 2005 in Jakarta. Initially, the Company was only engaged in the production of NC paints for the automotive and synthetic alkyd fields as well as anti-rust paints for the heavy metal industry. In subsequent developments, the company is trying to produce water-based decorative paints which are being loved by the Indonesian paint market.

PT Indaco Warna Dunia is headquartered in Surakarta, Central Java province, and is currently focused on developing water-based and solvent-based decorative paints. Its market reach includes retailers and wholesalers. In 2014 PT Indaco Coating Industri acquired its subsidiary, namely PT WarnaDunia which is engaged in distribution and sales, so it changed its name to PT Indaco Warna Dunia. PT Indaco Warna Dunia formed a joint venture with Northstar, a private equity company from Singapore in January 2015.

PT Indaco Warna Dunia produces superior brands including ENVI, BELAZO, TOP SEAL, and others which are pioneered, managed, and developed by competent Local Human Resources (HR). Currently, PT Indaco Warna Dunia has grown to become one of the largest and rapidly growing paint industries in 
Indonesia and already has 77 branches (depots) spread throughout Indonesia and headquartered in Karanganyar Regency.

PT Indaco Warna Dunia through the Harmoni Foundation expresses concern for the environment through its corporate social responsibility (CSR) program by working on Harmoni Village in Karangkidul, Pulosari Village, Kebakkramat, Karanganyar. In many cases, CSR has an important role in the community empowerment process. [11-17]

In this case, the company has implemented CSR for the community, including in the form of renovation of houses of worship, the establishment of Harmoni PAUD, and the Implementation of Harmoni Village. This study seeks to focus on Kampung Harmoni.

\section{Methods}

The method used in this research is a case study research method. The location of this research is in the harmony village in Karanganyar. The location was chosen because it is the location for the implementation of corporate social responsibility of PT. Indaco Colors of the World. This location is in Pulosari Village, Kebakkramat District. Karanganyar Regency. The Pulosari village includes five hamlets, namely Karangkidul, Gronong, Pengawat, Klolokan, and Pulosari. The population in this study is the community in the harmony village in Karanganyar. The reason is because Kampung Harmoni is the object of PT Indaco Warna Dunia's CSR.

The data collection techniques in this study were interviews, observations, and documentation. This study uses a data validity technique in the form of source triangulation. This study uses an interactive model of analysis data analysis technique by Miles and Huberman which consists of three main components of analysis, namely data reduction, data display, and conclusion drawing which is referred to as the interactive model of analysis [18].

\section{Result and Discussion}

PT Indaco Warna Dunia through the Harmoni Foundation expresses concern for the environment through its corporate social responsibility (CSR) program by working on Harmoni Village in Karangkidul, Pulosari Village, Kebakkramat, Karanganyar. The Harmoni Foundation works on eight neighborhood units (RT) in two community units (RW) located in two hamlets, namely Karangkidul and Dadagan . Each RT has the freedom to create Harmonious Villages according to the creations and innovations of residents. A total of 638 families were involved in these activities (as of 2018). Karangkidul Hamlet is the pilot project for Kampung Harmoni in Karanganyar Regency.

Kampung Harmoni is one of the Harmoni Foundation programs in collaboration with PT Indaco Warna Dunia. The concept of Kampung Harmoni is related to creating a beautiful and efficient surrounding environment. The ultimate goal is not only to create a village that can be enjoyed but also to provide benefits to improve the welfare of the community without damaging the surrounding environment. The 
empowerment does many empowering and sustainable act to save environment. The program are reforestation, environmental education through festivities, applying green concept in a building, hydroponic education, garbage bank, and etc. The contribution felt by the community is considered real and beneficial in a sustainable manner. The CSR uses unique strategy to empower people to protect environment in creative manners. The CSR's roles as a facilitator on the empowerment are:

\subsection{Social animation}

Social animation skills describe the ability of change agents or community empowerment to generate energy, inspiration, enthusiasm for the community, including activating, stimulating, and developing citizens' motivation to act. The role of change agents or community empowerment here is not as someone who will carry out all activities by himself, but rather to enable (enable) citizens to want to be actively involved in the process of change in the community.

\subsection{Mediation and negotiation}

Actors of change in an effort to carry out social intervention (planned social change) sometimes encounter situations where there are conflicts of interest and values in the community. This conflict is often unavoidable because in a community it is not uncommon to have different interests and perspectives from various groups in the community.

Related to the above, community empowerment must be able to carry out the function of mediation or become a mediator to connect groups in conflict in order to achieve synergy in the community. Role as a mediator is of course related to the role as negotiator because in the middle of the group that is in conflict, not infrequently a change agent should be able to mediate and find common ground which could be shared by groups that are in conflict without cause strife and division more profound. That is an empowering community shall not favor one among these communities

\subsection{Supporters}

One of the roles of community empowerment is to provide and develop support for citizens who want to be involved in the structure and activities of the community. The support itself is not always material, but can also be in the form of praise, appreciation in the form of words, or attitudes and behaviors that show support from the actors of change for what the residents are doing, such as providing time for residents if they want to talk to them to discuss the problems they face.

\subsection{Group facilitation}

Much of the time spent by change agents is spent in groups in society. Therefore, the effectiveness of the change agents as community empowerment will also be closely related to their skills to interact with small groups. This is where the ability 
to facilitate groups of community empowerment agents is tested because of the diversity of the community.

The groups in society are fundamentally a social capital because of the element norm (norms) and value (values) in that group as well as the absence of confidence that is a characteristic of social capital. The thing that matters is the offender can the changes facilitating groups - groups of residents to want to act constructively and work together to improve people's welfare in a more whole and not just to build one or two groups. In some situations, a community leader may play a facilitative role in the group. He can be involved as a group leader or as a group member to assist the group in achieving its goals effectively.

Various discussions about efforts to develop groups are always related to the roles of change agents as community empowerment. The first thing to do is to focus on helping the group to achieve the desired result (for example, help build a playground or help renovate people's houses), while the second is more focused on how to create the group. From the point of view, in the development of a community, it is precisely the process that plays a more major role than just the results to be achieved.

\section{Conclusion}

The CSR of PT. Indaco Warna Dunia engages with the local community to strengthen the environment. This study found that empowerment leads to a variety of empowering and long-term environmental actions. As an empowerment facilitator, CSR has aided the community in performing more environmental acts as part of the empowerment program.

\section{References}

1. M. Munasinghe, Environmental Economics and Sustainable Development (The World Bank, 1993)

2. A. Suryono, Dimensi-Dimensi Prima Teori Pembangunan (Universitas Brawijaya Press, 2010)

3. S. Beder, JR Aust Hist Soc 79, 72 (1993)

4. A. Saptari, Modul 1, (2009)

5. I. K. Alit, Jurnal Permukiman Natah 3, 34 (2005)

6. N. Y. Ghina, Kampung harmoni: Pengelolaan Lingkungan Berbasis Pemberdayaan Masyarakat (Digital Library UNS, 2017)

7. N. Shamadiyah, Agrifo: Jurnal Agribisnis Universitas Malikussaleh 2, 28 (2017)

8. N. R. Sulistiyorini, R. S. Darwis, and A. S. Gutama, SHARE: Social Work Journal 5, (2015)

9. D. P., A. B., and T. I.R, Jurnal Penamas Adi Buana 1, (2017)

10. N. L. P. Juniartini, Jurnal Bali Membangun Bali 1, 27 (2020)

11. A. Ro, Journal of Hospitality \& Tourism Research 41, 41 (2017)

12. M. Tsavdaridou, International Journal of Environment and Sustainable Development 13, 261 (2014) 
13. D. R. Wijayanti and S. Suryani, Procedia-Social and Behavioral Sciences 184, 171 (2015)

14. M. Ismail, Journal of International Social Research 2, (2009)

15. K. Rangan, L. Chase, and S. Karim, Harvard Business Review 93, 40 (2015)

16. A. Amran, M. M. Zain, M. Sulaiman, T. Sarker, and S. K. Ooi, Kajian Malaysia 31, 57 (2013)

17. D. Wu, C. Lin, and S. Liu, Finance Research Letters 18, 127 (2016)

18. Sugiyono, Metode Penelitian Kuantitatif, Kualitatif dan $R \& B$ (Alfabeta, Bandung, 2008) 